\title{
Telomerase activity levels in the surgical margin and tumour distant tissue of the squamous cell carcinoma of the head-and-neck
}

\author{
Eva-Maria Fabricius ${ }^{\mathrm{a}, *}$, Ulrike Gurr ${ }^{\mathrm{a}}$ and Gustav-Paul Wildner ${ }^{\mathrm{b}}$ \\ ${ }^{a}$ Clinic for Oral and Maxillofacial Surgery, Campus Virchow Hospital, Charité, Medical Faculty of the Humboldt \\ University of Berlin, Germany \\ ${ }^{\mathrm{b}}$ Formerly Department of Pathology, Robert-Rössle-Clinic, Campus Berlin-Buch, Charité, Medical Faculty \\ of the Humboldt University of Berlin, Germany
}

\begin{abstract}
The survival of patients with a head-and-neck squamous cell carcinoma is determined by loco-regional recurrence and second primary carcinomas. As a complement to histopathology, molecular changes of tumour marginal and tumour distant tissue may confirm curative surgical tumour extirpation. We tested telomerase activity with PCR-ELISA kits.

20 tumour margin biopsies were chosen by the surgeon from 20 patients. In addition, 3 tissue samples were taken from each of 20 additional patients, one from the carcinoma centre, the tumour margin and one distant from the tumour. 50\% of the carcinoma centres were telomerase-positive. Thirteen of the 40 tumour margin samples showed increased telomerase levels, and in 3 of these residual carcinoma was histopathologically detected. Six of the 20 tumour distant tissues revealed increased telomerase levels. Telomerase positivity in carcinoma-free tumour margins correlated with a good prognosis. Confirmation of the results in a larger patient group is needed.
\end{abstract}

Keywords: Head-and-neck cancer, squamous cell carcinoma, surgical tumour margin, telomerase, TRAP assay, ELISA

\section{Introduction}

Despite much concerted effort, successes in the therapy of head-and-neck cancers in the last 30 years have not brought any significant prolongation of the 5-year survival of these patients $[2,4,29,66]$. The incidence of these tumours is increasing, and despite curative therapy there is a high risk of recurrence and second primary tumours (SPTs) for patients with squamous cell carcinoma in this region $[2,47,92]$. Loco-regional recurrences could be caused by undetected individual tumour cells, i.e., minimal residual cancers [24,67,89]. Immunohistochemical examination, for example with monoclonal antibodies against epithelial epitopes ([25,

\footnotetext{
${ }^{*}$ Corresponding author: Dr. rer. nat. Eva-Maria Fabricius, Charité, Campus Virchow Hospital, Clinic for Oral and Maxillofacial Surgery, Medical Faculty of the Humboldt University of Berlin, Augustenburger Platz 1, D-13353 Berlin, Germany. Tel.: +49 030450 555398; Fax: +49 030450 555901; E-mail: evamaria.fabricius@charite.de.
}

$62,88]$, cf. [24]), makes the demonstration of these tumour cells easier.

According to the concept of field cancerization, to establish molecular changes as the cause of SPTs [47, 67,84], molecular-biological and genetic investigation in tumour adjacent and tumour distant tissues must be carried out and the findings compared with those of the original tumour $[6,8,9,39,47,58,59,67,77,80$, $81,84]$. The clinical significance of molecular-genetic changes is, however, as yet unclear [94]. Tumour markers are being sought which can identify molecular lesions in carcinoma-free tumour marginal and distant normal tissue [6-9]. Particular attention must be given to the molecular characterization of p53 mutants $[8,9$, 67]: 13 of 25 patients (52\%) showed p53-mutations. Only 5/13 patients $(38 \%)$ suffered recurrence. Partridge et al. [67] demonstrated p53 mutants in 6 of 18 patients $(28 \%)$. All 6 patients with and 3 patients without p53 gene mutations (25\%) suffered recurrence or metastases. 
Our results with wild type p53 and p53 mutants [44], corresponding with those of van der Toorn et al. [87], showed that the sensitivity of the immunohistochemical p53 detection is too low for the identification of patients who suffer recurrence. In the same patients we examined tissue for human papilloma viruses (HPV) in PCR. In 5 tissues from 2 of the 20 patients, we found high risk HPV (types 16 and 18) in the tumour centre, adjacent tumour margin, and in the case of one patient also in tumour distant tissue [40]. In an extensive nordic case control study, Mork et al. [55] demonstrated infection with HPV-16 as a risk factor for headand-neck tumours. Since both p53 and HPV might be involved in the activation of telomerase [38,56,91], we used detection of telomerase activity in our study.

Since 1994 [37] the activation of telomerase in tumours, including head-and-neck tumours, has been studied and used for the diagnostic and prognostic assessment of the course of disease [46,51,68,82]. Telomerase reactivation stabilizes telomere length. It is also associated with their elongation and acquisition of an infinite proliferative capacity for cellular immortalization [31]. Increased telomerase levels have also been demonstrated in carcinoma-free tissue adjacent to tumours [19,20,51,68], cf. [52]. Proof of telomerase has demonstrated sensitivity for single carcinoma cells in several studies $[26,79,91,95]$.

In this study, we wanted to investigate whether the expression of telomerase can be used for the characterization of carcinoma-free tumour marginal and tumour distant sections, and we sought to compare its significance in these sections with its significance in the carcinoma centre. We also compared the further course of disease in patients with telomerase-positive and telomerase-negative tissues.

\section{Material and methods}

\subsection{Tissue samples and cell lines}

To determine the ELISA cut-off value under our laboratory conditions we examined the telomerase levels in head-and-neck tissue samples from 40 tumour-free patients in our clinic (Table 1). The biopsies were harvested with the previous consent of the patients who were undergoing an unrelated surgical intervention. These were cryo-conserved and kept at $-80^{\circ} \mathrm{C}$.

We also investigated the telomerase activity of 4 cell lines in the logarithmic growth phase. The cell line XF 354 (kindly made available to us by the DKFZ Heidel- berg) had been established from a strongly keratinized primary squamous cell carcinoma in the floor of the mouth of a 51-year-old male patient. In addition, we acquired the cell lines UM-SCC 14A to 14C (made available with thanks to Prof. T.E. Carey, University of Michigan, USA). They originate from three different local recurrences of a squamous cell carcinoma of the floor of the mouth (T1 N0 M0; G2-G3) from a 58-year-old female patient after surgical therapy and radiation [30]. In every PCR, we used the cell line UMSCC $14 \mathrm{C}$ as positive control, and, after 25 minute inactivation at $85^{\circ} \mathrm{C}$, as negative control.

We examined 80 tissue samples from 40 patients of our clinic between 1994 and 1997 with squamous cell carcinoma of the head-and-neck region. The samples had to be cryo-conserved for the telomerase PCR. They were harvested by the surgeon from tumours which had been completely removed but had not yet been formalinized. Three tissue samples - one each from the tumour centre, the surgical margin and from a site approximately $2 \mathrm{~cm}$ from the tumour - were made available to us from each of 20 patients (Table 2). All 3 samples from each patient originated from the same surgical treatment. From 20 other patients we examined only the tissue adjacent to the tumour: Table 3. All samples were cryo-conserved and archived at $-80^{\circ} \mathrm{C}$.

In all cases, the histopathological diagnosis of the tissues was known. Parallel to a molecular-biological examination of telomerase we subjected at least two sections of ca. $4 \mu \mathrm{m}$ per cryo-conserved tissue sample to histopathological examination with hemalauneosin staining to determine whether they contained carcinoma.

\subsection{Detection of telomerase}

The telomerase levels were determined with the TRAP assay (telomeric repeat amplification protocol) as described by Kim et al. [37] with the easily reproducible TeloTAGGG telomerase PCR-ELISA kit (Roche Diagnostics/Mannheim, Cat. no. 1854666 [1, 28,96]) and a biotinylated primer. With this kit the products of amplification can be demonstrated after hybridization with a labelled probe in ELISA. As a rule, we used 3 and $0.5 \mu \mathrm{g}$ protein for the tissue and examined 0.01 to $0.5 \mu \mathrm{g}$ for the 4 cell lines per PCR. The protein concentration in the cell lysates was determined in accordance with Lowry et al. [49] with the Bio-Rad DC protein assay kit (Bio-Rad Laboratories, USA). 
Table 1

Telomerase levels in normal tissues from 40 patients without tumours for determination of cut-off value: tissues and patients' data

\begin{tabular}{|c|c|c|c|c|c|}
\hline Control-No. & Tissue sample from & Sex/age & Nicotine/alcohol abuse & Telomerase activity* & $\begin{array}{c}\text { Histo-pathological } \\
\text { evaluation }^{* *}\end{array}$ \\
\hline Co1 & normal buccal mucosa & $\mathrm{F} / 18$ & none & 0 & 0 \\
\hline $\mathrm{Co} 2$ & normal buccal mucosa & $\mathrm{M} / 20$ & unk & 0 & 0 \\
\hline $\mathrm{Co} 3$ & normal buccal mucosa & $\mathrm{M} / 20$ & none & 0 & 1 \\
\hline $\mathrm{Co} 4$ & normal buccal mucosa & $\mathrm{M} / 23$ & unk & 0 & 0 \\
\hline Co5 & normal buccal mucosa & $\mathrm{M} / 36$ & unk & 0 & 1 \\
\hline Co6 & normal buccal mucosa & $\mathrm{F} / 50$ & unk & 0 & 1 \\
\hline $\mathrm{Co} 7$ & normal mucosa (nose) & $\mathrm{F} / 46$ & unk & 1 & 0 \\
\hline Co8 & gingiva & $\mathrm{F} / 55$ & none & 0 & 0 \\
\hline $\mathrm{Co} 9$ & normal mucosa (tongue) & $\mathrm{M} / 30$ & none & 0 & 0 \\
\hline Co10 & normal mucosa $\mathrm{OPh}$ & $\mathrm{F} / 30$ & unk & 0 & 1 \\
\hline Co11 & OPh (scar) & $\mathrm{M} / 12$ & none & 0 & 1 \\
\hline Co12 & $\mathrm{OPh}$ & $\mathrm{M} / 58$ & none & 0 & 0 \\
\hline Co13 & $\mathrm{OPh}$ & $\mathrm{M} / 58$ & unk & 0 & 0 \\
\hline Co14 & lip (scar) & $\mathrm{M} / 1$ & none & 0 & 0 \\
\hline Co15 & lip (scar) & $\mathrm{M} / 3$ & none & 0 & 0 \\
\hline Co16 & lip (scar) & $\mathrm{F} / 15$ & none & 0 & 2 \\
\hline Co17 & normal skin (scalp) & $\mathrm{F} / 7$ & none & 0 & 0 \\
\hline Co18 & normal skin (scalp) & $\mathrm{F} / 10$ & none & 0 & 0 \\
\hline Co19 & normal skin (scalp) & $\mathrm{M} / 18$ & A & 0 & 0 \\
\hline $\mathrm{Co} 20$ & normal skin (scalp) & $\mathrm{F} / 30$ & none & 0 & 0 \\
\hline $\mathrm{Co} 21$ & normal skin (scalp) & $\mathrm{M} / 54$ & none & 0 & 0 \\
\hline $\mathrm{Co} 22$ & normal skin (ear) & $\mathrm{M} / 4$ & none & 0 & 0 \\
\hline $\mathrm{Co} 23$ & normal skin (ear) & $\mathrm{M} / 5$ & none & 0 & 0 \\
\hline Co 24 & normal skin (ear) & $\mathrm{F} / 7$ & none & 0 & 0 \\
\hline Co 25 & normal skin (ear) & $\mathrm{M} / 8$ & none & 0 & 0 \\
\hline Co 26 & normal skin (ear) & $\mathrm{M} / 15$ & none & 0 & 0 \\
\hline Co 27 & normal skin (ear) & $\mathrm{F} / 24$ & none & 0 & 0 \\
\hline Co 28 & normal skin (ear) & $\mathrm{M} / 31$ & none & 0 & 0 \\
\hline Co 29 & normal skin (ear) & $\mathrm{F} / 35$ & N/A & 0 & 0 \\
\hline Co 30 & normal skin (ear) & $\mathrm{F} / 44$ & none & 0 & 0 \\
\hline Co 31 & normal skin (nose) & $\mathrm{M} / 10$ & none & 0 & 0 \\
\hline Co 32 & normal skin (scar) & $\mathrm{M} / 12$ & none & 0 & 1 \\
\hline Co 33 & normal skin (scar) & $\mathrm{F} / 17$ & none & 0 & 0 \\
\hline Co 34 & normal skin (scar) & $\mathrm{M} / 34$ & unk & 0 & 0 \\
\hline Co 35 & normal skin (face) & $\mathrm{M} / 20$ & none & 0 & 0 \\
\hline Co 36 & normal skin (face) & $\mathrm{F} / 78$ & none & 0 & 0 \\
\hline Co 37 & atheroma eye & $\mathrm{F} / 41$ & none & 0 & 0 \\
\hline Co 38 & normal skin (eye) & M/11 & none & 0 & 0 \\
\hline Co 39 & normal skin (eye; scar) & $\mathrm{M} / 46$ & none & 0 & 0 \\
\hline Co 40 & normal skin (eyelid) & $\mathrm{F} / 57$ & none & 0 & 0 \\
\hline
\end{tabular}

$\mathrm{M}=$ male; $\mathrm{F}=$ female; $\mathrm{OPh}=$ oropharynx; none = no or minimal nicotine and alcohol; unk = unknown; $\mathrm{A}=$ alcohol abuse $(>70 \mathrm{~g} /$ day $) ; \mathrm{N} / \mathrm{A}=$ nicotine ( $>20$ cigarettes/day) and alcohol abuse;

$*$ Value of telomerase activity: $0=$ negative $=0-150 \mathrm{mOD} ; 1+=150-450 \mathrm{mOD} ; 2+=450-750 \mathrm{mOD} ; 3+=750-1050 \mathrm{mOD} ; 4+=$ above $1050 \mathrm{mOD}$;

**Evaluation of normal tissues: $0=$ no lymphocytic and/or granulocytic infiltration; $1=$ sparse to low infiltration; $2=$ moderate lymphocytic infiltration. 
Table 2

Telomerase activity (TA) of carcinoma tissue and carcinoma-free samples from 20 patients with head-and-neck squamous cell carcinoma and the clinical and histopathological details

\begin{tabular}{|c|c|c|c|c|c|c|c|c|c|c|c|}
\hline No. & $\begin{array}{l}\text { Tumour } \\
\text { site }\end{array}$ & Sex/age & $\begin{array}{c}\text { TNM } \\
\text { classification* }\end{array}$ & $\begin{array}{c}\text { Tumour } \\
\text { stage }\end{array}$ & $\begin{array}{l}\text { Tumour } \\
\text { grading }\end{array}$ & $\begin{array}{c}\text { Nicotine/ } \\
\text { alcohol } \\
\text { abuse }\end{array}$ & $\mathrm{TA}^{-\mathrm{TC}^{* *}}$ & TA-TM** & $\begin{array}{c}\text { Histopatho- } \\
\text { logical } \\
\text { evaluation of } \\
\text { tumour } \\
\text { margin*** }\end{array}$ & TA-TD ${ }^{* *}$ & $\begin{array}{c}\text { Histopatho- } \\
\text { logical } \\
\text { evaluation of } \\
\text { tumour distan } \\
\text { tissue }\end{array}$ \\
\hline 1 & $\begin{array}{l}\text { buccal } \\
\text { mucosa }\end{array}$ & $\mathrm{F} / 76$ & pT3pN1 & III & G2 & none & 0 & 1 & 1 and 4 & 0 & 1 \\
\hline 2 & gingiva & $\mathrm{M} / 59$ & pT4pN2 & IVA & G2 & N/A & 2 & 0 & 2 & 1 & 3 \\
\hline 3 & gingiva & $\mathrm{M} / 66$ & pT1pNO & I & G3 & A & 1 & 0 & 2 & 0 & $1-2$ \\
\hline 4 & FoM & $\mathrm{M} / 39$ & pT3pN2 & IVA & G3 & N/A & 0 & 0 & 1 & 4 & 3 \\
\hline 5 & FoM & $\mathrm{M} / 50$ & pT4pN1 & IVA & G3 & none & 1 & 0 & $1-2$ & 0 & 1 \\
\hline 6 & FoM & $\mathrm{M} / 61$ & pT2pN2 & IVA & G3 & $\mathrm{A}$ & 1 & 0 & 1 & 0 & 0 \\
\hline 7 & FoM & $\mathrm{M} / 63$ & pT2pN0 & II & G2 & N/A & 1 & $1^{* * * *}$ & $1-2$ & 1 & 1 \\
\hline 8 & FoM & $\mathrm{F} / 65$ & pT2pNO & II & G2 & none & 1 & $0 * * * *$ & 2 & 1 & 1 \\
\hline 9 & $\begin{array}{l}\text { FoM/ } \\
\text { tongue }\end{array}$ & $\mathrm{M} / 50$ & pT2pN2 & IVA & G2 & N/A & 0 & 1 & 2 & 0 & 1 \\
\hline 10 & $\begin{array}{l}\text { FoM/ } \\
\text { tongue }\end{array}$ & $\mathrm{M} / 52$ & pT4pN0 & IVA & G3 & none & 0 & $0 * * * *$ & 1 & 0 & 1 \\
\hline 11 & $\begin{array}{l}\text { FoM/ } \\
\text { tongue }\end{array}$ & $\mathrm{M} / 52$ & pT1pN0 & I & G2 & A & 0 & 1 & $1-2$ & 0 & 1 \\
\hline 12 & $\begin{array}{l}\text { FoM/ } \\
\text { tongue }\end{array}$ & $\mathrm{M} / 52$ & pT4pN0 & IVA & G2 & none & 0 & $0 * * * *$ & 2 & 4 & 3 and 4 \\
\hline 13 & $\begin{array}{l}\text { FoM/ } \\
\text { upper jaw }\end{array}$ & $\mathrm{F} / 72$ & pT2pN2 & IVA & G2 & none & 1 & $2^{* * * *}$ & $1-2$ & 0 & 1 \\
\hline 14 & tongue & $\mathrm{M} / 45$ & pT3pN2 & IVA & G3 & N/A & 0 & $0 * * * *$ & 1 & 0 & 1 \\
\hline 15 & tongue & $\mathrm{M} / 58$ & pT2pN1 & III & G2 & none & 0 & 0 & 2 & 3 & 3 \\
\hline 16 & tonsil & $\mathrm{M} / 55$ & pT2pN1 & III & G3 & none & 4 & 1 & 1 & 0 & 0 \\
\hline 17 & alveolus & $\mathrm{F} / 61$ & pT4pN0 & IVA & $\mathrm{G} 2$ & none & 4 & $4^{* * * *}$ & 2 & 0 & 1 \\
\hline 18 & ear & $\mathrm{M} / 58$ & pT4pN1 & IVA & G3 & none & 3 & 1 & $1-2$ & 0 & 1 \\
\hline 19 & ear & $\mathrm{M} / 75$ & pT4pN1 & IVA & G2 & none & 0 & 0 & 0 & 0 & 1 \\
\hline 20 & $\begin{array}{l}\text { relapse } \\
\text { under M. } \\
\text { sternocl. }\end{array}$ & $\mathrm{M} / 58$ & pT3pN2 & IVA & G3 & N/A & 0 & 1 & 0 & 0 & 2 \\
\hline
\end{tabular}

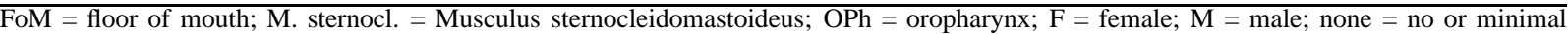
nicotine and alcohol; $\mathrm{N}=$ nicotine abuse $(>20$ cigarettes/day); $\mathrm{A}=$ alcohol abuse $(>70 \mathrm{~g} / \mathrm{day}) ; \mathrm{N} / \mathrm{A}=$ nicotine and alcohol abuse; TC $=$ tissues from tumour centre; $\mathrm{TM}=$ tissues from tumour margin; $\mathrm{TD}=$ carcinoma-free tumour distant tissues.

*All patients were M0 (without distant metastases).

${ }^{* *}$ Value of telomerase activity: $0=$ negative $=0-150 \mathrm{mOD} ; 1+=150-450 \mathrm{mOD} ; 2+=450-750 \mathrm{mOD} ; 3+=750-1050 \mathrm{mOD} ; 4+=$ above $1050 \mathrm{mOD}$.

${ }^{* * *}$ Evaluation of adjacent tumour margin as well as tumour distant tissue: $0=$ no lymphocytic and/or granulocytic infiltration; $1=$ sparse to low infiltration; 2 = moderate lymphocytic infiltration; 3 = strong lymphocytic and granulocytic infiltration; $4=$ pre-cancerous lesion (dysplasia 1 with acanthosis).

$* * * *$ Tumour margin with residual cancer. 
Table 3

Telomerase activity (TA) of carcinoma-free samples from tumour margin of 20 patients with head-and-neck squamous cell carcinoma and the clinical and histopathological details

\begin{tabular}{|c|c|c|c|c|c|c|c|c|}
\hline No. & Tumour site & Sex/age & $\begin{array}{c}\text { TNM } \\
\text { classification* }\end{array}$ & $\begin{array}{l}\text { Tumour } \\
\text { stage }\end{array}$ & $\begin{array}{l}\text { Tumour } \\
\text { grading }\end{array}$ & $\begin{array}{l}\text { Nicotine/ } \\
\text { alcohol } \\
\text { abuse }\end{array}$ & TA-TM** & $\begin{array}{c}\text { Histopathological } \\
\text { evaluation of } \\
\text { tumour margin } * * *\end{array}$ \\
\hline 21 & buccal mucosa & $\mathrm{M} / 58$ & pT4pN3 & IVB & $\mathrm{G} 2$ & none & 1 & $1-2$ and 4 \\
\hline 22 & buccal mucosa & $\mathrm{M} / 58$ & pT1pN0 & I & $\mathrm{G} 2$ & none & 0 & 1 \\
\hline 23 & cheek & $\mathrm{M} / 55$ & pT1pN1 & III & G3 & none & 0 & 1 \\
\hline 24 & cheek & $\mathrm{F} / 71$ & pT3pN0 & III & G1 & none & 0 & 2 \\
\hline 25 & FoM & $\mathrm{F} / 43$ & pT1pN0 & I & G2 & $\mathrm{N}$ & 0 & 1 \\
\hline 26 & FoM & $\mathrm{M} / 49$ & $\mathrm{pT} 2 \mathrm{pN} 1$ & III & G2 & N/A & 0 & 1 \\
\hline 27 & FoM & $\mathrm{M} / 52$ & pT1pN0 & I & G2 & none & 0 & 1 \\
\hline 28 & FoM & $\mathrm{M} / 63$ & pT1pN0 & I & G2 & A & 1 & $2-3$ \\
\hline 29 & FoM/tongue & $\mathrm{M} / 42$ & $\mathrm{pT} 4 \mathrm{pN} 2$ & IVA & $\mathrm{G} 2$ & A & 0 & $1-2$ \\
\hline 30 & FoM/tongue & $\mathrm{F} / 48$ & pT4pN2 & IVA & G2 & A & 0 & 2 \\
\hline 31 & FoM/tongue & $\mathrm{M} / 53$ & $\mathrm{pT} 2 \mathrm{pN} 0$ & II & G3 & A & 0 & 1 \\
\hline 32 & FoM/tongue & $\mathrm{M} / 54$ & pT1pN0 & I & G3 & N/A & 0 & 0 \\
\hline 33 & tongue & $\mathrm{M} / 50$ & pT1pN0 & I & G3 & A & 0 & 2 \\
\hline 34 & tongue & $\mathrm{M} / 52$ & pT1pN0 & I & G1 & A & 1 & 1 and 4 \\
\hline 35 & tongue & $\mathrm{F} / 64$ & $\mathrm{pT} 2 \mathrm{pN} 2$ & IVA & G3 & none & 0 & 1 \\
\hline 36 & tongue/OPh & $\mathrm{M} / 57$ & pT1pN0 & I & $\mathrm{G} 2$ & N/A & 0 & 1 \\
\hline 37 & $\mathrm{OPh}$ & $\mathrm{M} / 52$ & $\mathrm{pT} 2 \mathrm{pN} 2$ & IVA & G3 & $\mathrm{A}$ & 0 & 1 \\
\hline 38 & lip & $\mathrm{F} / 59$ & $\mathrm{pT} 2 \mathrm{pN} 0$ & II & G2 & A & 0 & 1 \\
\hline 39 & lip & $\mathrm{M} / 74$ & $\mathrm{pT} 2 \mathrm{pN} 0$ & II & $\mathrm{G} 2$ & $\mathrm{~N}$ & 2 & 1 \\
\hline 40 & nose & $\mathrm{F} / 89$ & $\mathrm{pT} 2 \mathrm{pN} 0$ & II & $\mathrm{G} 2$ & none & 0 & 0 \\
\hline
\end{tabular}

FoM = floor of mouth; OPh = oropharynx; $\mathrm{F}=$ female; $\mathrm{M}=$ male.

*All patients were M0 (without distant metastases); none = no or minimal nicotine and alcohol; $\mathrm{N}=$ nicotine abuse $(>20$ cigarettes/day); $\mathrm{A}=$ alcohol abuse $(>70 \mathrm{~g} /$ day $) ; \mathrm{N} / \mathrm{A}=$ nicotine and alcohol abuse; $\mathrm{TA}=$ telomerase activity; $\mathrm{TM}=$ tissues from tumour margin

${ }^{* *}$ Value of telomerase activity: $0=$ negative $=0-150 \mathrm{mOD} ; 1+=150-450 \mathrm{mOD} ; 2+=450-750 \mathrm{mOD} ; 3+=750-1050 \mathrm{mOD} ; 4+=$ above $1050 \mathrm{mOD}$.

*** Evaluation of adjacent tumour-margin tissue: $0=$ no lymphocytic and/or granulocytic infiltration; $1=$ sparse to low infiltration; $2=$ moderate lymphocytic infiltration; 3 = strong lymphocytic und granulocytic infiltration; 4 = pre-cancerous lesion (dysplasia 1 with acanthosis).

\subsection{Verification of negative results}

\subsubsection{Checking taq polymerase inhibition}

In all telomerase-negative tissues we examined whether the false negative results were attributable to a taq polymerase inhibition, and we used an internal 216 bp homologous amplification standard from a TeloTAGGG telomerase PCR-ELISA ${ }^{\text {Plus }}$ kit (Roche Diagnostics/Mannheim, Cat. no. 2013 789). The standard must always show a positive result with a regular PCR in PCR-ELISA. We defined the ELISA extinction value for the internal standard as at least $500 \mathrm{mOD}$. If the result with the standard in the telomerase-negative tissue at 3 and $0.5 \mu \mathrm{g}$ protein per PCR was negative, we reduced the quantity of protein to 0.1 and $0.01 \mu \mathrm{g}$ protein per PCR until the PCR result with the standard was positive. We then repeated the telomerase PCR with this protein quantity and the same lysate.

\subsubsection{Checking for telomerase inhibition}

We tested all negative lysates for telomerase inhibition. In each PCR we mixed the corresponding negative lysate with the lysate from our positive control $(0.063 \mu \mathrm{g}$ protein from the lysate of cell line UM-SCC 14C, cf. Fig. 1) and compared the telomerase levels with and without negative tissue lysate [42]. As a rule, we used $3 \mu \mathrm{g}$ protein of the negative lysate from our tissue samples. Since some lysates showed an inhibition of the taq polymerase (for an examination of this inhibition cf. 2.3.1.), we used protein dilutions from the lysates which were only uninhibited in the PCR with the internal standard.

\subsection{Statistics}

For the statistic calculations [70] we worked with SPSS 10.0 for Windows and used the Contingency Ta- 


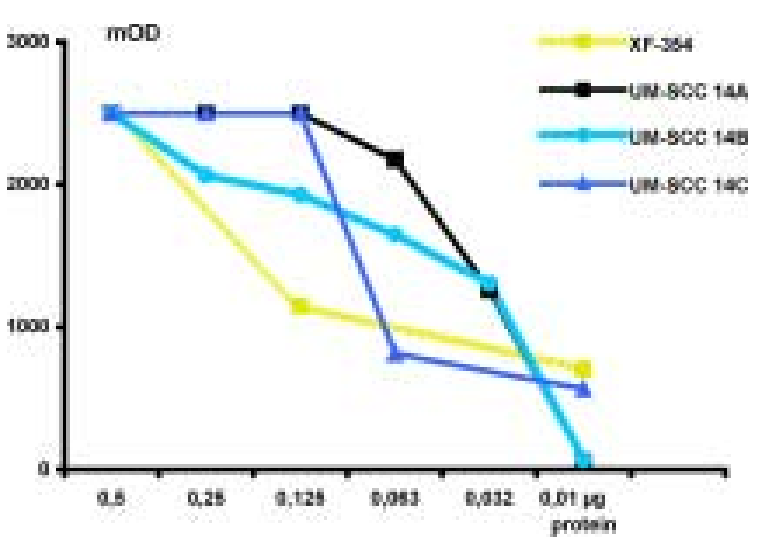

Fig. 1. Telomerase activity in the tumour cell lines XF-354 and UM-SCC $14 \mathrm{~A}$ to $14 \mathrm{C}$.

bles, including the calculation of the $\mathrm{Chi}^{2}$ value und the Fisher Exact Test from the J.C. Pezzullo Webpage (University of Georgetown, USA). All statistical comparisons are 2-sided.

\section{Results}

\subsection{Telomerase findings in normal tissue samples to determine the PCR-ELISA cut-off}

From the telomerase levels of the 40 tumour-free tissue samples (Table 1) the mean plus the double value of the standard deviation yielded a cut-off value
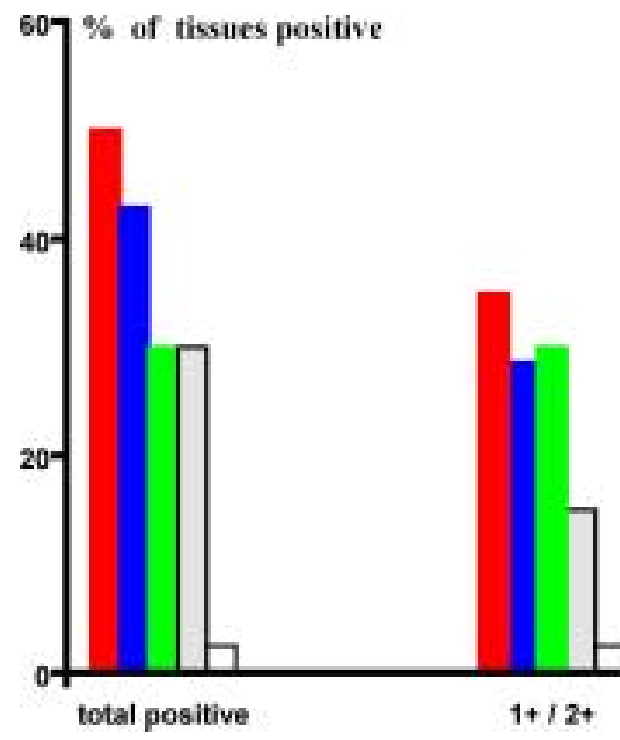

rounded up to $150 \mathrm{mOD}$ extinction. The telomerase level of one of the 40 normal tissue samples (3\%) was above the cut-off and was thus categorized positive (Sample 7 with a telomerase extinction value of 187 mOD, cf. Table 1). We set a quantitative extinction value of the telomerase activity as follows: negative up to $150 \mathrm{mOD} ; 1+=150-450 \mathrm{mOD} ; 2+=450$ $750 \mathrm{mOD} ; 3+=750-1050 \mathrm{mOD} ; 4+=$ above 1050 mOD.

\subsection{Telomerase activation in cell lines}

All four cell lines showed high telomerase levels. There was no significant difference between the telomerase activity of the cell line from a primary tumour (XF 354) and the three cell lines of various different recurrences (UM-SCC 14A to 14C): Fig. 1 (Wilcoxon test: $p>0.05)$.

\subsection{Telomerase activity in samples from tumour patients}

Table 2 (cf. Fig. 2) lists the telomerase levels of the 3 tissue samples taken from each patient together with the patients' data. Ten of 20 tumour centre tissues were telomerase-positive $(50 \%)$ with values between $1+$ and $4+$. This result is comparable with the telomerase activation in 3 of the 7 tumour margin samples with residual carcinoma (43\%) and values between $1+$ to $4+(U$-test by Mann and Whitney: $p=0.868$; ex-

Etumour centro $(n=20)$

- tumour margin with residual carcinoma $(n=7)$

E carcinoma-free tumour margin (n $=33$ )

Dcarcinoma-free tumour-distant tissue $(n=20)$

Dnomal tissues from patients without tumours $(n=40)$

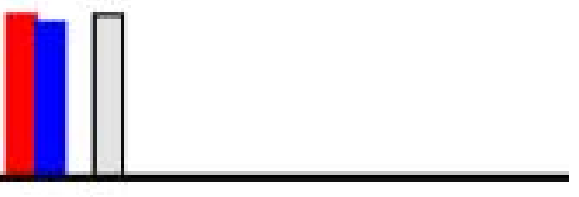

$3+14+$

Fig. 2. Telomerase activity in the tissue samples examined. Values of telomerase activity: negative $=0-150 \mathrm{mOD} ; 1+=150-450 \mathrm{mOD} ; 2+=$ 450-750 mOD; $3+=750-1050 \mathrm{mOD} ; 4+=$ above $1050 \mathrm{mOD}$. 
tinction value - not listed $-p=0.561)$. In these 7 patients we compared the values of the tumour centres and tumour margin tissues with residual carcinoma. Two patients revealed different values for telomerase activation (No. 8 and 13).

Ten of the 33 carcinoma-free tumour marginal tissue samples $(30 \%)$ were telomerase-positive, with lower telomerase levels of between $1+$ and $2+$ (Fig. 2, Tables 2 and 3 ) and 6 of 20 carcinoma-free tumour distant tissues (30\%) showed levels between $1+$ and $4+$ ( $U$-test by Mann and Whitney: $p=0.971$; extinction values - not listed $-p=0.369$ ). In the three patients with very high telomerase levels in tumour distant tissues (patient no. 4, 12 and 15) the samples from the tumour centres and the tumour margin were telomerase-negative (Table 2). The rate of telomerasepositive samples from the tumour patients did not differ significantly among the individual tissue sections (Fisher Exact test: $p>0.05$ ). The rate of telomerasepositive tissues from the tumour patients was significantly higher than the normal tissue of the tumourfree patients (Table 1) (Fisher Exact test: normal tissue to tumour centre tissue: $p=<0.001$, tumour margins with residual carcinoma: $p=0.008$, carcinomafree tumour margins: $p=0.001$ and tumour distant tissue: $p=0.004$ ). In a statistical comparison of the extinction values of the telomerase acivity in the individual tissue samples of tumour patients, the values of the tumour marginal sections were significantly lower than in the tumour centre tissue: $U$-test by Mann and Whitney: $p=0.00374$.

\subsection{Histopathological evaluation of the carcinoma-free tumour margins and tumour distant tissues}

To interpret the telomerase levels in the carcinomafree tumour margins and tumour distant tissues, a histopathological evaluation of the lymphocytic or granulocytic infiltration and proof of dysplastic changes were needed: Tables 2 and 3. Statistically we found no significance between the rate of telomerase activity and the rate of infiltration of mononuclear cells in the carcinoma-free tumour margin tissue (Contingency $2 \times 2$ Tables - Chi ${ }^{2}$-test: $\left.p=0.161\right)$ and no significance in the tumour distant tissue $(p=0.057)$. Likewise, we compared telomerase activity of tissue samples from carcinoma-free patients (Table 1) with the rate of mononuclear cell infiltrations: $p=0.897$.

\subsection{Proof of PCR inhibition in the negative samples to identify false negative results}

\subsubsection{Proof of inhibition of taq polymerase in the negative samples}

We tested the 39 telomerase-negative tissue lysates from normal tissue of the tumour-free patients (Table 1) and 51 telomerase-negative lysates from tumour patients' tissue (Tables 2 and 3) with the internal amplification standard (compare Material and methods, 2.3.1.) to determine whether an inhibition of the PCR was attributable to false negative telomerase results (Table 4).

Five of the 39 normal tissues showed an inhibition with the internal amplification standard at $3 \mu \mathrm{g}$ protein (samples 2, 12, 14, 22 and 24, cf. Table 1) and became positive with the internal standard at $0.5 \mu \mathrm{g}$ protein/PCR. Only one specimen (sample 6, Table 1) reacted with the internal standard positive at $0.1 \mu \mathrm{g}$ protein per assay. A repeat PCR of the 39 samples with $0.1 \mu \mathrm{g}$ protein per assay was once again negative in the telomerase PCR.

All of the 51 lysates from the tumour patients with telomerase-negative tissue showed an inhibition of the taq polymerase: Table 3 . In 21 inhibited specimens the internal standard was negative only at $3 \mu \mathrm{g}$ protein/PCR. Thirteen negative samples were inhibited at 3 and at $0.5 \mu \mathrm{g}$ and one negative sample was inhibited at 3 , at 0.5 as well as at $0.1 \mu \mathrm{g}$ protein/PCR. When using reduced protein dilutions which yielded a positive PCR with the internal standard, all 51 samples were once again telomerase-negative.

\subsubsection{Proof of telomerase inhibition in negative samples}

We tested inhibition of telomerase in the telomerasenegative lysates. We mixed lysates with our positive control (cf. 2.3.2. ) [42]. Only one tissue lysate (No. 33 , Table 3) revealed a moderate telomerase inhibition along with a moderate taq polymerase inhibition (Table 4, No. 33) and a moderate lymphocytic infiltration (Table 3).

\subsection{Correlation of telomerase findings with clinical data and tumour follow-up}

A comparison of our telomerase results and tumour staging and grading showed no correlation with tumour size, lymph node status or with tumour grading ( $U$-test by Mann and Whitney: $p>0.05$ ).

In the context of our study, we also examined whether the patients' further course of disease can be 
Table 4

Examination of telomerase-negative tissue samples with the internal standard from patients with head-and-neck squamous cell carcinoma (cf. 2.3.1. Material and methods as well as Tables 2 and 3)

\begin{tabular}{|c|c|c|c|c|}
\hline \multirow[t]{2}{*}{ No. } & \multicolumn{4}{|c|}{$\begin{array}{l}\text { Inhibitory limit of internal standard } \\
\text { with } 3,0.5 \text { or } 0.1 \mu \mathrm{g} \text { protein/PCR }\end{array}$} \\
\hline & $\mathrm{TC}$ & TM-C & TM-F & TD \\
\hline 1 & none & & & none \\
\hline 2 & & & none & \\
\hline 3 & & & none & none \\
\hline 4 & 3 and $0.5 \mu \mathrm{g}$ & & 3 and $0.5 \mu \mathrm{g}$ & \\
\hline 5 & & & $3 \mu \mathrm{g}$ & none \\
\hline 6 & & & 3 and $0.5 \mu \mathrm{g}$ & $3 \mu \mathrm{g}$ \\
\hline 7 & & & & \\
\hline 8 & & none & & \\
\hline 9 & none & & & 3 and $0.5 \mu \mathrm{g}$ \\
\hline 10 & none & none & & none \\
\hline 11 & none & & & $3 \mu \mathrm{g}$ \\
\hline 12 & none & 3 and $0.5 \mu \mathrm{g}$ & & \\
\hline 13 & & none & & none \\
\hline 14 & $3,0.5$ and $0.1 \mu \mathrm{g}$ & 3 and $0.5 \mu \mathrm{g}$ & & $3 \mu \mathrm{g}$ \\
\hline 15 & 3 and $0.5 \mu \mathrm{g}$ & & $3 \mu \mathrm{g}$ & \\
\hline 16 & & & & none \\
\hline 17 & & & & none \\
\hline 18 & & & & none \\
\hline 19 & 3 and $0.5 \mu \mathrm{g}$ & & none & none \\
\hline 20 & 3 and $0.5 \mu \mathrm{g}$ & & 3 and $0.5 \mu \mathrm{g}$ & \\
\hline 21 & & & & \\
\hline 22 & & & $3 \mu \mathrm{g}$ & \\
\hline 23 & & & none & \\
\hline 24 & & & none & \\
\hline 25 & & & 3 and $0.5 \mu \mathrm{g}$ & \\
\hline 26 & & & 3 and $0.5 \mu \mathrm{g}$ & \\
\hline 27 & & & none & \\
\hline 28 & & & & \\
\hline 29 & & & none & \\
\hline 30 & & & none & \\
\hline 31 & & & $3 \mu \mathrm{g}$ & \\
\hline 32 & & & none & \\
\hline 33 & & & $3 \mu \mathrm{g}$ & \\
\hline 34 & & & & \\
\hline 35 & & & none & \\
\hline 36 & & & none & \\
\hline 37 & & & none & \\
\hline 38 & & & none & \\
\hline 39 & & & & \\
\hline 40 & & & & none \\
\hline
\end{tabular}

None = PCR non-inhibited; TC $=$ tissues from tumour centre, TM$\mathrm{C}=$ tissues from tumour margin with residual carcinoma; $\mathrm{TM}-\mathrm{F}=$ tissues from carcinoma-free tumour margin; TD = carcinoma-free tumour distant tissues. predicted by using the telomerase activation measured in the tumour margin tissue samples as a marker. Figure 3 shows that patients with a telomerase activation suffered recurrent disease or death less frequently, although the difference is not significant (Fisher Exact test: $p>0.05$ ). This is supported by a Kaplan-Meier curve of the 33 patients with carcinoma-free tumour marginal tissue (Fig. 4): Log Rank 0.1744 (mean relapse time of telomerase-positive patients 52 months, of telomerase-negative patients 35 months). The Cox's proportional hazard regression model with recurrence as event revealed for covariates telomerase activity in the tumour margin samples ( $p=0.202)$, tumour stage $(p=0.049)$, tumour grading $(p=0.639)$ and nicotine and/or alcohol abuse $(p=0.637)$ significance only for the tumour stage.

\section{Discussion}

The high rate of loco-regional recurrence and second primary tumours, which are decisive for the 5-year survival of patients $[4,24,29,66,92]$, has been the object of intense investigation. Histopathologically undetectable molecular changes in a field cancerization process [78] are thought to be involved in the high rate of second primary tumours $[11,15,50,65,90]$. Bedi et al. [3] and Scholes et al. [73] have explored the possibility of a common clonal origin of multiple tumours [23].

Single tumour cells - "minimal residual disease" - in surgical tumour margins [8,9,24,62,87], lymph nodes near the tumour $[67,88]$, bone marrow $[7,24,25$, 62] cf. [63] or peripheral blood [7,88] could also be responsible for recurrence or metastasis.

Since 1996 researchers have been investigating the role of telomerase reactivation in head-and-neck tumours in clinical application [51]. The aim of our study was to examine telomerase activation as a complement to histopathology to identify molecular changes in normal tumour marginal tissue and in normal tumour distant tissue. For comparison we examined carcinoma centres.

\subsection{Telomerase activity in tumour cell lines}

The PCR-ELISA kits from Roche Diagnostics offer a convenient method of demonstrating telomerase, as seen in the reproducible results achieved over a longer time period using the cell line UM-SCC 14C in all PCRs as positive control (cf. Fig. 1). Mao et al. [51] also demonstrated significant telomerase activation in the cell lines UM-SCC 14A and 14B, and Sumida et al. [83] showed that other oral SCC cell lines also have high telomerase levels. 


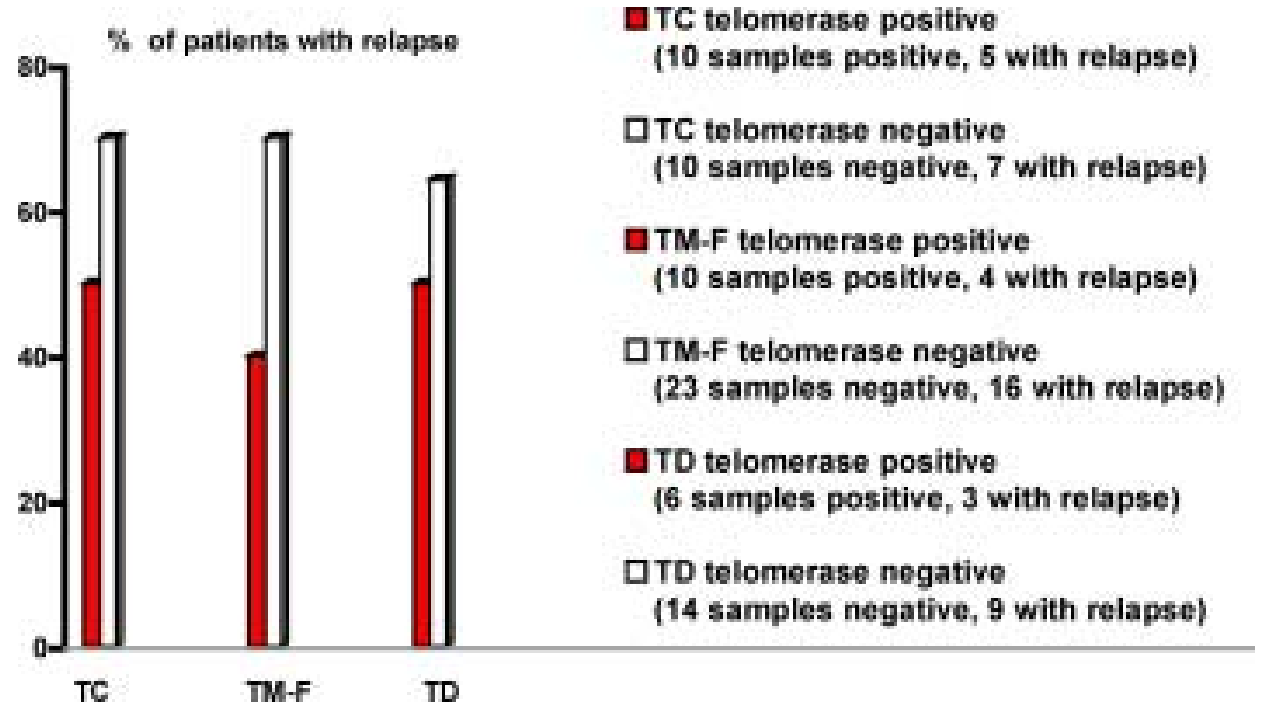

Fig. 3. Rate of relapse in relation to telomerase activity: 12 of $20(60 \%)$ patients with tumour centre (TC) and tumour distant tissue (TD), and 20 of $33(61 \%)$ patients with carcinoma-free tumour-margin tissues (CFM) suffered relapse in period of observation.

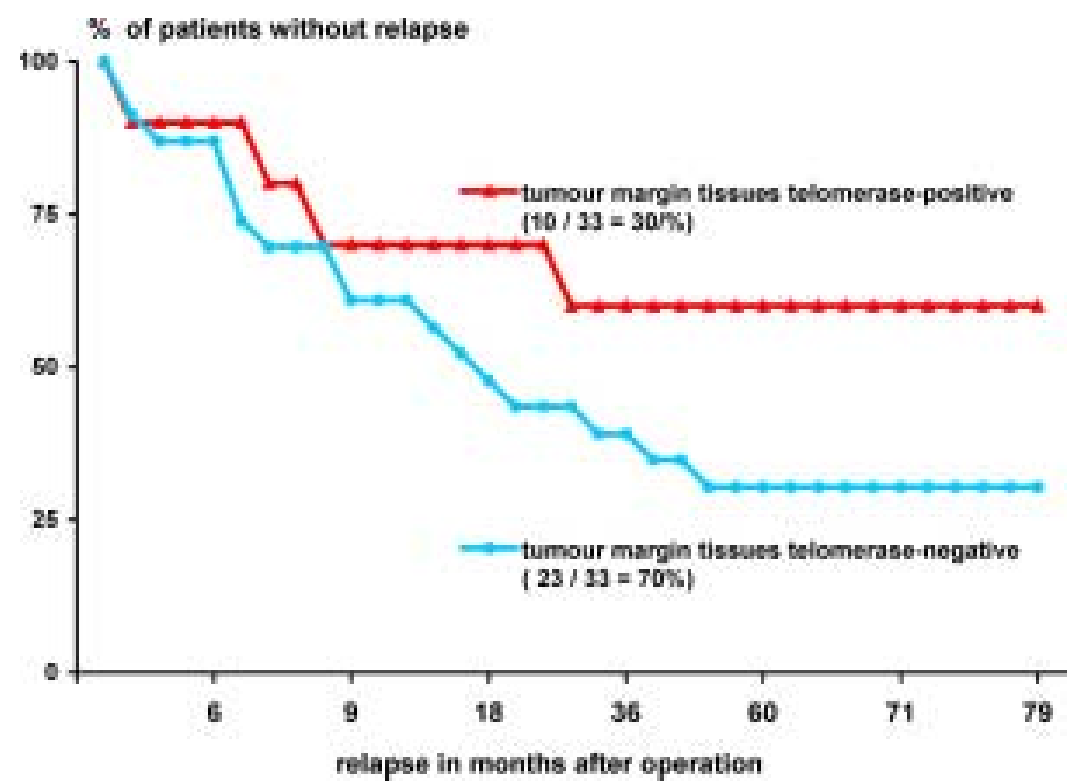

Fig. 4. Postoperative course of disease in relation to telomerase activity investigated in 33 carcinoma-free tumour margins: Kaplan-Meier curve (Log Rank $p=0.1744$.

\subsection{Telomerase levels in carcinoma centres}

Ries et al. [69] found an increase in telomerase levels by $46 \%$ in oral carcinomas, a finding in accordance with our study (50\%, cf. Fig. 2). There is a clear difference in the results reported by Sumida et al. [83] and Thurnher et al. [85]: 100\%; Mao et al. [51] and Curran et al. [19]: 90\%; Mutirangura et al. [57]: 88\%; Chang et al. [13]: 86\%; Liao et al. [46]: 82\%; Kannan et al. [36]: 75\%; Califano et al. [10]: 74\%; and Patel et al. [68]: 78\%. Dhaene et al. [20] also determined an overall increase of $94 \%$.

In comparison to the strong telomerase activity found by most investigators, our results with lower telomerase activation may have various causes. We know from the work of Carey et al. [12] on mammal carcinoma tissue, that a carefully controlled histopathological selection of tissue specimens can raise the 
proportion of telomerase-positive samples from 78 to $95 \%$. For this reason, the authors recommend harvesting tissue by means of micro-dissection. In our study, we got tiny tissue pieces from the surgical material not needed for histopathological diagnostics. Therefore, the tissues were not always optimally harvested. On the other hand, our tissue material was immediately deep-frozen, which minimizes breakdown of telomerase by RNases.

For confirmation of telomerase activation in our study it was important to exclude false negative telomerase results. With the reduced quantity of protein per PCR we eliminated inhibition of the taq polymerase. The telomerase levels remained negative in all cases. According to Sumida and Hamakawa [82], inhibition of taq polymerase may be caused by interference with necrotic material in the synthesis of telomerase or with the PCR by inflammatory cells or by bacteria in the carcinoma tissue. Boukamp (P. Boukamp (2001), personal communication, cf. [21]) discovered an inhibition of the taq polymerase through the presence of heparin. Matthes et al. (E. Matthes et al. (2001), in preparation, cf. [21]) investigated heparin with various molecular weights in a TRAP assay. At the inhibiting concentration using the high-molecular weight heparin, only the amplification of the telomeres was inhibited, not the amplification of their internal standard.

Mast cells secrete heparin after degranulation. They were demonstrated in and around tumours [18,60] and might have been present in the tissues we examined. Noga et al. [61] revealed that the heparin secreted in vivo from the mast cells of human lungs has a higher molecular weight. In our study the internal standard was amplified after reduction of the protein quantity/PCR in all telomerase-negative lysates. In further studies we will investigate whether our results can be improved by washing the tissue sections previous to lysis and optimizing tissue selection for the telomerase identification [12]. By doing so, Chaves-Dias et al. [14] were able to demonstrate a temporary telomerase activation in normal proliferating mast cells in cultures from peripheral blood and permanent non-inhibited telomerase levels in malignant mast cell lines. It is possible that by washing the cells previous to lysis they had removed heparin from their culture-medium.

\subsection{Telomerase activation in carcinoma-free tumour margin and tumour distant tissues}

As a main objective in our study we examined telomerase levels in normal tumour marginal and nor- mal tumour distant tissues: Fig. 2. Contrary to the control patients, $3 \%$ of whom (1/40, cf. Table 1$)$ showed increased telomerase level in tissues without carcinoma, $30 \%$ of the tumour patients had increased telomerase levels in all carcinoma-free tissue samples: Tables 2 and 3. Our findings are comparable with the telomerase-positive tumour adjacent tissues found by Mao et al. [51] - 11/29 specimens (38\%), by Curran et al. [19] - 7/20 (35\%), by Ries et al. [69] - 1/3 (33\%), and in the review compiled by Dhaene et al. [20]-7/20 (35\%). In the study by Patel et al. [68] using the same Roche Diagnostics test kit used in our study, the telomerase activity was significantly higher $(20 / 27=74 \%)$.

It is conceivable that the increased telomerase values of our study in $30 \%$ of the carcinoma-free tumour marginal tissue samples and in $30 \%$ of the tumour distant tissues are primarily or partially associated with infiltration by lymphatic or inflammatory cells. In the tumour margins and the tumour distant tissues we demonstrated lymphocytic and granulocytic infiltrates of varying intensity (cf. 3.4.): Tables 2 and 3. After in vitro stimulation of normal peripheral mononuclear blood cells, above all $\mathrm{T}$ and $\mathrm{B}$ lymphocytes, a telomerase activation can be demonstrated which varies with the age of the test person [35] and depends on the nature of the stimulation $[5,32,35,48,86,97]$. Telomerase is activated after contact with antigens [35]. Thus, all three tumour distant samples with high telomerase levels (patients No. 4, 12 and 15, Table 2) contained lymphatic tissue elements and might be interpreted in this direction.

The stimulation of infiltration of mononuclear cells could also be the explanation for the fact that in one of the tonsillar carcinomas examined, the telomerase levels were very high, both in the carcinoma centre and in the carcinoma-free marginal tissue (Table 2, sample 16). The activity level of telomerase in the carcinoma could have added to the activity in the lymphatic tissue. In an earlier investigation using the PCR, we detected high risk HPV (human papilloma virus) type 16 and 18 both in the tumour centre and in the carcinomafree tumour marginal and tumour distant tissues [40]. The tumour distant tissue infected by HPV, which was antigen-stimulated, showed no telomerase activity. Despite the high telomerase levels in the tumour centre and tumour margin, the prognosis of this patient was good. In 88 months of tumour post-operative followup, the patient suffered no recurrence or metastasis. This one case could correspond to the findings reached in 253 patients by Gillison et al. [27]. 62 patients in whom they demonstrated high risk HPV Type 16 had a 
better prognosis than HPV-negative patients. The HPV patients however also had lower tobacco and alcohol consumption than the HPV-negative patients. Mellin et al. [53] explained these unexpected findings with an antigenic heterogenization of the HPV infected tumour and an increased immunoresistance. Mork et al. [55] point to HPV infection as being a patient risk factor independent of tobacco consumption.

Further investigation is necessary to determine telomerase activation through in situ detection of hTERT expression (a human protein catalytic subunit of telomerase). Immunohistochemistry or in situ hybridization should clarify which cells participate in telomerase activation, above all in carcinoma-free tumour adjacent and tumour distant tissues $[22,33,43,45,93,98]$.

\subsection{Telomerase activation, cancer risk factors and course of disease}

Some researchers are looking to the demonstration of molecular or genetic lesions as a means of assessing and predicting patients at high risk of a second primary tumour $[6,16,17,71,72,80,84]$. According to Patel et al. [68] immortal cells in various sites and a field cancerization process [78] may be the reason for the high telomerase activation in carcinoma-free adjacent and distant tissues. These telomerase levels are explained by the multiple mutational steps of carcinogenesis [75]. Risk factors, e.g., tobacco and alcohol abuse, are believed to be potential causative factors $[15,17,65$, $90]$. We compared our telomerase results in the tumour marginal and tumour distant tissue with the data on patient nicotine and alcohol abuse. Statistically, neither nicotine nor alcohol abuse correlated significantly with the rate of telomerase activity in the carcinoma-free tumour marginal or tumour distant tissues (Fisher Exact test: tumour marginal tissues $p=0.440$, tumourdistant tissues $p=0.574$ ). We found a comparable frequency for telomerase-negative tissue in patients with alcohol and/or nicotine abuse: Tables 2 and 3 .

In an 8-year study by Papadimitrakopoulou et al. [64] the mean risk of an oral leukoplakia becoming tumorous was $36 \%$. Sudbö et al. [80,81], in a follow-up study lasting approximately 8 years, reported a mean carcinoma risk of $24 \%$ (36/150 patients) depending upon the ploidy status: $3 \%$ (diploid lesions) and $84 \%$ (aneuploid lesions). Of the total of 163 pre-cancerous lesions investigated, increased levels of telomerase activity were recorded in 103 tissue samples (63\%) [10, $13,46,57,68,69,74,83]$ ranging between the extremes of $39 \%$ [57] and $100 \%$ [68]. This common result from retrospective studies suggests that telomerase activation in pre-cancerous oral lesions may be a useful marker for cancer risk assessment. Prospective studies warrant investigation into telomerase activation in early carcinogenesis and comparison with genomic and proliferation markers [41].

In this study we tested the relation of telomerase reactivation in tumour marginal and distant regions with the postoperative recurrence rate of our patients. Although statistically not significant, the incidence of telomerase activation was associated with a better course of disease (Figs 3 and 4). This is contradictory to our expectations and seems controversial. In the 88 months since surgery, the tonsillar carcinoma patient (No. 16, Table 2) has had no recurrence, despite high levels of telomerase activity in the carcinoma centre and moderate levels in the tumour margin.

The telomerase activation in tumour marginal and distant tissue might be partially due to the presence of telomerase-competent infiltrating mononuclear cells. On the other hand, telomerase activity was found only in one of 40 cases with histopathologically normal epithelium of the oral mucosa in the non-tumour patients (Table 1). It must yet be clarified whether these lymphocytes are evidence of a specific activation of a local immunodefence against genetically damaged mucosa of oral carcinogenesis.

\section{Conclusion}

One object of this investigation into telomerasepositive tumour adjacent normal tissue was the question of whether an adjuvant anti-telomerase therapy could be a specific approach to head-and-neck cancer therapy. The individual cells in carcinoma-free margins and tumour distant sites which are affected by telomerase activation must be identified using an in situ method. In this way it should be possible to distinguish between telomerase-involved field cancerization with immortal cell clones and telomerase activation which rather indicates interfering cell-mediated immunoreaction.

Once this question has been clarified, telomerase detection might become a useful biomarker for cancer risk assessment when patients with head-and-neck carcinoma are being considered for an adjuvant therapy based on specific telomerase inhibition [34,54,76]. The unexpectedly improved prognosis of the patients with telomerase-positive tumour-adjacent tissues could be an argument against systemic anti-telomerase therapy. This result must be confirmed with an extensive follow-up in a larger patient group. 


\section{Acknowledgements}

We thank Mrs. C. Aubel for language help and Mrs. U. Kruse-Boitschenko for her technical aid in the laboratory.

\section{References}

[1] T. Akao, Y. Kakehi, X.-X. Wu, H. Kinoshita, T. Takahashi, O. Ogawa, T. Kato and O. Yoshida, Semi-quantitative analysis of telomerase activity of exfoliated cells in urine of patients with urothelial cancers: Causative factors affecting sensitivity and specificity, Urologic Oncology 3 (1998), 118-124.

[2] Arbeitsgemeinschaft Bevölkerungsbezogener Krebsregister in Deutschland in Zusammenarbeit mit dem Robert-KochInstitut, Krebs in Deutschland - Häufigkeiten und Trends. 2. Aktualisierte Ausgabe, Saarbrücken (1999), 1-64.

[3] G.C. Bedi, W.H. Westra, E. Gabrielson, W. Koch and D. Sidransky, Multiple head and neck tumors: Evidence for a common clonal origin, Cancer Res. 56 (1996), 2484-2487.

[4] J. Bier, A. Moegelin, B. Hell and H. Gath, Onkologie 2000 - Denkbare Entwicklungen für Kopf-Halstumoren, Der Onkologe 1 (1996), 46-49.

[5] A. Bodnar, N. Kim, R. Effros and C.-P. Chiu, Mechanism of telomerase induction during $\mathrm{T}$ cell activation, Exp. Cell. Res. 228 (1996), 58-64.

[6] B.J.M. Braakhuis, M.P. Tabor, C.R. Leemans, I. van der Waal, G.B. Snow and R.H. Brakenhoff, Second primary tumors and field cancerization in oral and oropharyngeal cancer: Molecular techniques provide new insight and definitions, Head Neck 24 (2002), 198-206.

[7] R.M. Brakenhoff, J. Stroomer, C. ten Brink, R. de Bree, S. Weima, G. Snow and G.A.M.S van Dongen, Sensitive detection of squamous cells in bone marrow and blood of head and neck cancer patients by E48 reverse transcriptase-polymerase chain reaction, Clin. Cancer Res. 5 (1999), 725-732.

[8] J.A. Brennan, L. Mao, R.H. Hruban, J.O. Boyle, Y.J. Eby, W.M. Koch, S.N. Goodman and D. Sidransky, Molecular assessment of histopathological staging in squamous-cell carcinoma of the head and neck, New Engl. J. Med. 332 (1995), 429-435.

[9] J.A. Brennan and D. Sidransky, Molecular staging of head and neck squamous carcinoma, Cancer Metastasis Rev. 15 (1996), 3-10.

[10] J. Califano, S.A. Ahrendt, G. Meininger, W.H. Westra, W.M. Koch and D. Sidransky, Detection of telomerase activity in oral rinses from head and neck squamous cell carcinoma patients, Cancer Res. 56 (1996), 5720-5722.

[11] J. Califano, P. van der Riet, W.H. Westra, H. Nawroz, G. Clayman, S. Piantadosi, R. Corio, D. Lee, B. Greenberg, W. Koch and D. Sidransky, Genetc progression model for head and neck cancer: Implications for field cancerisation, Cancer Res. 56 (1996), 2488-2492.

[12] L.A. Carey, C.A. Hedican, G.S. Henderson, C.B. Umbricht, J.S. Dome, D. Varon and S. Sukumar, Careful histological confirmation and microdissection reveal telomerase activity in otherwise telomerase-negative breast cancers, Clin. Cancer Res. 4 (1998), 435-440.
[13] L.Y. Chang, S.C. Lin, C.S. Chang, Y.K. Wong, Y.C. Hu and K.W. Chang, Telomerase activity and in situ telomerase RNA expression in oral carcinogenesis, J. Oral Pathol. Med. 28 (1999), 389-396.

[14] C. Chaves-Dias, T.R. Hundley, A.M. Gilfillan, A.S. Kirshenbaum, J.R. Cunha-Melo, D.D. Metcalfe and M.A. Beaven, Induction of telomerase activity during development of human mast cells from peripheral blood $\mathrm{CD}_{3}{ }^{+}$cells: Comparison with tumor mast-cell lines, J. Immunol. 166 (2001), 66476656.

[15] F. Cianfriglia, D. Di Gregorio and A. Manieri, Multiple primary tumours in patients with oral squamous cell carcinoma, Oral Oncol. 35 (1999), 157-163.

[16] J. Cloos, C.R. Leemans, M.L.T. van der Sterre, D.J. Kuik, G.B. Snow and B.J.M. Braakhuis, Mutagen sensitivity as a biomarker for second primary tumors after head and neck squamous cell carcinoma, Cancer Epidemiology Biomarkers and Prevention 9 (2000), 713-717.

[17] J. Cloos, C.B. Reid, G.B. Snow and B.J. Braakhuis, Mutagen sensitivity: enhanced risk assessment of squamous cell carcinoma, Eur. J. Cancer B Oral Oncol. 32B (1996), 367-372.

[18] L.M. Coussens and Z. Werb, Inflammatory cells and cancer: think different!, J. Exper. Med. 193 (2001), F23-F26.

[19] A.J. Curran, K.S. Denis, J. Irish, P.J. Gullane, C. MacMillan and S. Kamel-Reod, Telomerase activity in oral squamous cell carcinoma, Arch. Otolaryngol. Head Neck Surg. 124 (1998), 784-788.

[20] K. Dhaene, E. Van Marck and R. Parwaresch, Telomeres, telomerase and cancer: an up-date, Virchows Arch. 437 (2000), $1-16$.

[21] H. Engelberg, Actions of heparin that may affect the malignant process, Cancer 85 (1999), 257-272.

[22] M. Frost, J.B. Bobak, R. Gianani, N. Kim, S. Weinrich, D.C. Spalding, L.G. Cass, L.C. Thompson, T. Enomoto, D. Uribe-Lopez and K.R. Shroyer, Localization of telomerase hTERT protein and hTR in benign mucosa, dysplasia, and squamous cell carcinoma of the cervix, Am. J. Clin. Pathol. 114 (2000), 726-734.

[23] S.B. Garcia, H.S. Park, M. Novelli and N.A. Wright, Field cancerization, clonality, and epithelial stem cells: the spread of mutated clones in epithelial sheets, J. Pathol. 187 (1999), 61-81.

[24] H.J. Gath and R.H. Brakenhoff, Minimal residual disease in head and neck cancer, Cancer and Metastasis Rev. 18 (1999), 109-126.

[25] H.J. Gath, E. Heissler, B. Hell, J. Bier, G. Riethmüller and K. Pantel, Immunocytologic detection of isolated tumor cells in bone marrow of patients with squamous cell carcinomas of the nead and neck region, Int. J. Oral. Maxillofac. Surg. 24 (1995), 351-355.

[26] L.R. Gauthier, C. Granotier, J.-C. Soria, S. Faivre, V. Boige, E. Raymond and F.D. Boussin, Detetion of circulating carcinoma cells by telomerase activity, Brit. J. Cancer 84 (2001), 631-635.

[27] M.L. Gillison, W.M. Koch, R.B. Capone, M. Spafford, W.H. Westra, L. Wu, M.L. Zahurak, R.W. Daniel, M. Viglione, D.E. Symer, K.V. Shah and D. Sidranski, Evidence for a causal association between human papillomavirus and a subset of head neck cancer, J. Natl. Cancer Inst. 92 (2000), 709-720. 
[28] R. Gonzalez-Quevedo, C. de Juan, M.J. Massa, A. SanchezPernaute, A. Torres, J.L. Balibrea, M. Benito and P. Iniesta, Detection of telomerase activity in human carcinomas using a trap-ELISA method: correlation with hTR and hTERT expression, Int. J. Oncol. 16 (2000), 623-628.

[29] R.T. Greenlee, M.B. Hill-Harmon, T. Murray and M. Thun, Cancer Statistics, 2001, CA Cancer J. Clin. 51 (2001), 15-36.

[30] R. Grenman, T.E. Carey, K.D. McClatchey, J.G. Wagner, K. Pekkola-Heino, D.R. Schwartz, G.T. Wolf, L.P. Lacivita, L. Ho and A.S. Lichter, In vitro radiation resistance among cell lines established from patients with squamous cell carcinoma of the head and neck, Cancer 67 (1991), 2741-2747.

[31] C.B. Harley, N.W. Kim, K.R. Prowse, S.L. Weinrich, K.S. Hirsch, M.D. West, S. Bacchetti, H.W. Hirte, C.M. Counter, C.W. Greider, M.A. Piatszek, W.E. Wright and C.M. Shay, Telomerase, cell immortality, and cancer, Cold Spring Harb. Symp. Quant. Biol. 59 (1994), 307-315.

[32] K. Hiyama, Y. Hirai, S. Kyoizumi, M. Akiyama, E. Hiyama, M.A. Piatyszek, J.W. Shay, S. Ishioka and M. Yamakido, Activation of telomerase in human lymphocytes and hematopoietic progenitor cells, J. Immunol. 155 (1995), 3711-3715.

[33] E. Hiyama, K. Hiyama, T. Yokoyama and J.W. Shay, Immunohistochemical detection of telomerase (hTERT) protein in human cancer tissues and a subset of cells in normal tissues, Neoplasia 3 (2001), 17-26.

[34] R. Hodes, Molecular targeting of cancer: Telomeres as targets, Proc. Natl. Acad. Sci. (USA) 98 (2001), 7649-7651.

[35] H. Igarashi and N. Sakaguchi, Telomerase activity is induced in human peripheral B lymphocytes by the stimulation to antigen receptor, Blood 89 (1997), 1299-1307.

[36] S. Kannan, H. Tahara, H. Yokazaki, B. Mathew, K.R. Nalinakumari, M.K. Nair and E. Tahara, Telomerase activity in premalignant and malignant lesions of human oral mucosa, Cancer Epidemiol. Biomarkers Prev. 6 (1997), 413-420.

[37] N.W. Kim, M.A. Piatyszek, K.R. Prowse, C.B. Harley, M.D. West, P.L. Ho, G.M. Coviello, W.E. Wright, S.L. Weinrich and J.W. Shay, Specific association of human telomerase activity with immortal cells and cancer [see comments], Science 266 (1994), 2011-2015.

[38] A.J. Klingelhutz, S.A. Foster and J.K. McDougall, Telomerase activation by the E6 gene product of human papillomavirus type 16, Nature 380 (1996), 79-82.

[39] W.M. Koch, J.O. Boyle, L. Mao, J. Hakim, R.H. Hruban and D. Sidransky, p53 gene mutations as marker of tumor spread in synchronous oral cancers, Arch. Otolaryngol. Head Neck Surg. 120 (1994), 943-947.

[40] S.R. Kowalski, Nachweis von Papillomvirus-DNA in KopfHals-Tumoren und Tumorrandgebieten mit der PCR, Medizinische Dissertation, Humboldt-Universität-Berlin, 2001, pp. 1-93.

[41] G. Krupp, G. Bonatz and R. Parwaresch, Telomerase, immortality and cancer, Biotechnol. Annu. Rev. 6 (2000), 103-140.

[42] F. Lancelin, M. Anidjar, J.-M. Villette, A. Soliman, P. Teillac, A. Le-Duc, J. Fiet and O. Cussenot, Telomerase activity as a potential marker in preneoplastic bladder lesions, B.J.U. International 85 (2000), 526-531.

[43] B. Lee, E. Diebel, F.W. Neukamp, J. Wiltfang and J. Ries, Diagnostic and prognostic relevance of expression of human telomerase subunits in oral cancer, Int. J. Oncol. 19 (2001), 10631068 .
[44] K. Lehmann, Immunhistochemischer Nachweis von p53, bcl-2 und mdm-2 in Kopf-Hals-Tumoren unter Berücksichtigung der Tumorrandgewebe, Medizinische Dissertation, HumboldtUniversität-Berlin, 2000, pp. 1-86.

[45] R. Lehner, J. Bobak, N.W. Kim, A.L. Shroyer and K.R. Shroyer, Localization of telomerase hTERT protein and survivin in placenta: relation to placental development and hydatidiform mole, Obstet. Gynecol. 97 (2001), 965-970.

[46] J. Liao, T. Mitsuyasu, K. Yamane and M. Ohishi, Telomerase activity in oral and maxillofacial tumors, Oral Oncology 36 (2000), 347-352.

[47] S.M. Lippman and W.K. Hong, Molecular markers of the risk of oral cancer, New Engl. J. Med. 344 (2001), 1323-1326

[48] K. Liu, M.M. Schoonmaker, B.L. Levine, C.H. June, R.J. Hodes and N.P. Wenig, Constitutive and regulated expression of telomerase reverse transcriptase (hTERT) in human lymphocytes, Proc. Natl. Acad. Sci. (USA) 96 (1999), 51475152.

[49] O.H. Lowry, N.J. Rosenbrough, L. Farr and R.J. Randall, Protein measurement with the folin phenol reagent, J. Biol. Chemistry 193 (1951), 265-275.

[50] W.M. Lydiatt, P.E. Anderson, T. Bazzana, M. Casale, C.J. Hughes, A.G. Huvos, D.D. Lydiatt and S.P. Schantz, Molecular support for field cancerization in the head and neck, Cancer 82 (1998), 1376-1380.

[51] L. Mao, A.K. El-Naggar, Y.-H. Fan, J.S. Lee, S.M. Lippman, S. Kayser, R. Lotan and W.K. Hong, Telomerase activity in head and neck squamous cell carcinoma and adjacent tissues, Cancer Res. 56 (1996), 5600-5604.

[52] P. Matthews and C.J. Jones, Clinical implications of telomerase detection, Histopathology 38 (2001), 485-498.

[53] H. Mellin, S. Friesland, R. Lewensohn, R. Dalianis and E. Munck-Wikland, Human papillomavirus (HPV) DNA in tonsillar cancer: clinical correlates, risk of relapse, and survival, Int. J. Cancer 89 (2000), 300-304.

[54] M. Meyerson, Role of telomerase in normal and cancer cells, J. Clin. Oncol. 18 (2000), 2626-2634.

[55] J. Mork, A.K. Lie, E. Glattre, G. Hallmans, E. Jellum, P. Koskela, B. Möller, E. Pukkala, J.T. Schiller, L. Youngman, M. Lehtinen and J. Dillner, Human papillomavirus infection as a risk factor for squamous-cell carcinoma of the head and neck, N. Engl. J. Med. 344 (2001), 1125-1131.

[56] A. Mutirangura, V. Sriuranpong, W. Termrunggraunglert, D. Tresukosol, P. Lertsaguansinchai, N. Voravud and S. Niruthisard, Telomerase activity and human papillomavirus in malignant, premalignant and benign cervical lesions, $B r . J$. Cancer 78 (1998), 933-939.

[57] A. Mutirangura, P. Supiyaphun, S. Trirekapan, V. Sriuranpong, A. Sakuntabhai, S. Yenrudi and N. Voravud, Telomerase activity in oral leukoplakia and head and neck squamous cell carcinoma, Cancer Res. 56 (1996), 3530-3533.

[58] C.A. Nathan, S. Franklin, F.W. Abreo, R. Nassar, A. de Benedetti and J. Glass, Analysis of surgical margins with the molecular marker eIF4E: a prognostic factor in patients with head and neck cancer, J. Clin. Oncol. 17 (1999), 2909-2914.

[59] C.A. Nathan, L. Liu, B.D. Li, F.W. Abreo, I. Nandy and A. de Benedetti, Detection of the proto-oncogen eIF4E in surgical margins may predict recurrence in head and neck cancer, Oncogene 15 (1997), 579-584. 
[60] H. Nechushtan and E. Razin, Regulation of mast cell growth and proliferation, Crit. Rev. Oncol. Hematol. 23 (1996), 131150.

[61] O. Noga, T. Brunnée, C. Schäper and G. Kunkel, Heparin, derived from the mast cells of human lungs is responsible for the generation of kinins in allergic reactions due to the activation of tha contact system, Int. Arch. Allergy Immunol. 120 (1999), 310-316.

[62] K. Pantel, H. Gath and E. Heissler, Staging of head and neck cancer (letter; comment), New Engl. J. Med. 332 (1995), 1788, discussion 1789-1790.

[63] K. Pantel, G. Schlimok, M. Angstwurm, D. Weckermann, W. Schmaus, H. Gath, B. Passlick, J.R. Izbicki and G. Riethmüller, Methodological analysis of immunocytochemical screening for disseminated epithelial tumor cells in bone marrow, J. Hematotherapy 3 (1994), 163-173.

[64] V.A. Papadimitrakopoulou, W.K. Hong, J.S. Lee, J.W. Martin, J.J. Lee, J.G. Batskis and S.M. Lippman, Low-dose isotretinoin versus $\beta$-carotene to prevent oral carcinogenesis: Long-term follow-up, J. Natl. Cancer Inst. 89 (1997), 257-258.

[65] V.A. Papadimitrakopoulou, D.M. Shin and W.K. Hong, Molecular and cellular biomarkers for field cancerization and multistep process in head and neck tumorigenesis, Cancer Metastasis Rev. 15 (1996), 53-76.

[66] D.M. Parkin, P. Pisani and J. Ferlay, Global cancer statistics, CA Cancer J. Clin. 49 (1999), 33-64.

[67] M.L. Partridge, S.R. Li, S. Pateromichelakis, R. Francis, E. Phillips, X.H. Huang, F. Tesfa-Selase and J.D. Langdon, Detection of minimal residual cancer to investigate why oral tumors recur despite seemingly adequate treatment, Clin. Cancer Res. 6 (2000), 2718-2725.

[68] M.M. Patel, D.D. Patel, L.J. Parekh, G.N. Raval, R.M. Rawal, J.M. Bhatavdekar, B.P. Patel and P.S. Patel, Evaluation of telomerase activation in head and neck cancer, Oral Oncology 35 (1999), 510-515.

[69] J.C. Ries, E. Hassfurther, H. Steininger, F.R. Kloss, J. Wiltfang, S.C. Girod and F.W. Neukamp, Correlation of telomerase activity, clinical prognosis and therapy in oral carcinogenesis, Anticancer Res. 21 (2001), 1057-1063.

[70] L. Sachs, Angewandte Statistik. Anwendung statistischer Methoden, 7. Aufl., Springer-Verlag, Berlin-Heidelberg-New York, 1991, pp. 1-848.

[71] S.P. Schantz, Q. Huang, K. Shah, V.V. Murty, T.C. Hsu, G. Yu, P.E. Andersen, A.G. Huvos and R.S. Chaganti, Mutagen sensitivity and environmental exposures as contributing causes of chromosome $3 p$ losses in head and neck cancers, Carcinogenesis 21 (2000), 1239-1246.

[72] S.P. Schantz, M.R. Spitz and T.C. Hsu, Mutagen sensitivity in patients with head and neck cancers: A biologic marker for risk of multiple primary malignancies, J. Natl. Cancer Inst. 82 (1990), 1773-1775.

[73] A.G.M. Scholes, J.A. Woolgar, M.A. Boyle, J.S. Brown, E.D. Vaughan, C.A. Hart, A.S. Jones and J.K. Field, Synchronous oral carcinomas: independent or common clonal origin?, Cancer Res. 58 (1998), 2003-2006.

[74] J.W. Shay and S. Bacchetti, A survey of telomerase activity in human cancer, Eur. J. Cancer 33 (1997), 787-791.
[75] J.W. Shay and W.E. Wright, The reactivation of telomerase activity in cancer progression, Trends Genetics 12 (1996), 129131.

[76] J.W. Shay, Y. Zou, E. Hiyama and W.E. Wright, Telomerase and cancer, Human Molecular Genetics 10 (2001), 677-685.

[77] D. Sidransky, J. Boyle and W. Koch, Molecular screening: Prospects for a new approach, Arch. Otolaryngol. Head Neck Surg. 119 (1993), 1187-1190.

[78] D.P. Slaughter, H.W. Southwick and W. Smejka, "Field cancerization" in oral stratified squamous epithelium, Cancer 6 (1953), 963-968.

[79] J.C. Soria, L.R. Gauthier, E. Raymond, C. Granotier, L. Morat, J.P. Armand, F.D. Boussin and L. Sabatier, Molecular detection of telomerase-positive circulating epithelial cells in metastatic breast cancer patients, Clin. Cancer Res. 5 (1999), 971-975.

[80] J. Sudbö, M. Bryne, A.C. Johannessen, W. Kildal, H.E. Danielsen and A. Reith, Comparison of histological grading and large-scale genomic status (DNA ploidy) as prognostic tools in oral dysplasia, J. Pathol. 194 (2001), 303-310.

[81] J. Sudbö, W. Kildal, V. Risberg, H. Koppang, H. Danielsen and A. Reith, DNA content as a prognostic marker in patients with oral leukoplakia, New Engl. J. Med. 344 (2001), 1270-1278.

[82] T. Sumida and H. Hamakawa, Telomerase and oral cancer, Oral Oncology 37 (2001), 333-340.

[83] T. Sumida, H. Hamakawa, K. Sogawa, A. Sugita, H. Tanioka and N. Ueda, Telomerase components as a diagnostic tool in human oral lesions, Int. J. Cancer 80 (1999), 1-4.

[84] M.P. Tabor, R.H. Brakenhoff, V.M. van Houten, J.A. Kummer, M.H. Snel, P.J. Snijders, G.B. Snow, C.R. Leemans and B.J. Braakhuis, Persistence of genetically altered fields in head and neck cancer patients: biological and clinical implications, Clin. Cancer Res. 7 (2001), 1523-1532.

[85] D. Thurnher, B. Knerer, M. Formanek and J. Kornfehl, Nonradioactive semiquantitative testing for expression levels of telomerase activity in head and neck squamous cell carcinomas may be indicate for biological tumour behaviour, Acta Otolaryngol. (Stockh.) 118 (1998), 423-427.

[86] W. Tu, D.K. Zhang, P.T. Cheung, S.W. Tsao and Y.L. Lau, Effect of insulin-like growth factor 1 on PHA-stimulated cord blood mononuclear cell telomerase activity, Br. J. Haematol. 104 (1999), 785-794.

[87] P.-P.G. van der Toorn, J.A. Veltman, F.J. Bot, J.M.A. de Jong, J.J. Manni, F.C.S. Ramaekers and A.H.N. Hopman, Mapping of resection margins of oral cancer for p53 overexpression and chromocome instability to detect residual (pre)malignant cells, J. Pathol. 193 (2001), 66-72.

[88] G.A.M.S. van Dongen, R.M. Brakenhoff, C. ten Brink, F.B. van Gog, R. de Bree, J.J. Quak and G.B. Snow, Squamous cell carcinoma-associated antigens used in novel strategies for the detection and treatment of minimal residual head and neck cancer, Anticancer Res. 16 (1996), 2409-2414.

[89] V.M. van Houten, M.P. Tabor, M.W. van den Brekel, F. Denkers, R.G. Wishaupt, J.A. Kummer, G.B. Snow and R.H. Brakenhoff, Molecular assays for the diagnosis of minimal residual head-and-neck cancer: methods, reliability, pitfalls, and solutions, Clin. Cancer Res. 6 (2000), 3803-3816.

[90] M.G.C.T. van Oijen and P.J. Slootweg, Oral field cancerization: carcinogen-induced independent events or micrometastatic deposits?, Cancer Epidemiol. Biomarkers Prev. 9 (2000), 249256. 
[91] M.A. Vasef, J.S. Ross and M.B. Cohen, Telomerase activity in human solid tumors. Diagnostic utility and clinical applications, Am. J. Clin. Pathol. 112 (1999), S68-S75.

[92] E.E. Vokes, R.R. Weichselbaum, S.M. Lippman and W.K. Hong, Head and neck cancer, New Engl. J. Med. 328 (1993), 184-194.

[93] H. Wada, T. Enomoto, K. Yoshino, K. Ozaki, H. Kurachi, T. Nomura, Y. Murata, N. Kim, S. Weinrich, E. Lea-Chou, D. Lopez-Uribe and K.R. Shroyer, Immunohistochemical localization of telomerase hTERT protein and analysis of clonality in multifocal vulvar intraepithelial neoplasia, Am. J. Clin. Pathol. 114 (2000), 371-379.

[94] S. Warnakulasuriya, Histological grading of oral epithelial dysplasia: revisited, J. Pathol. 194 (2001), 294-297.

[95] T. Weber and E. Klar, Minimal residual disease in thyroid carcinoma, Seminars Surg. Oncol. 20 (2001), 272-277.
[96] Y.Y. Wu, A.M. Hruszkewycz, R.M. Delgado, A. Yang, A.O. Vortmeyer, Y.W. Moon, R.J. Weil, Z. Zhuang and A.T. Remaley, Limitations on the quantitative determination of telomerase activity by the electrophoretic and ELISA based TRAP assays, Clin. Chim. Acta 293 (2000), 199-212.

[97] O. Yamada, T. Motoji and H. Mizoguchi, Up-regulation of telomerase activity in human lymphocytes, Biochim. Biophys. Acta 1314 (1996), 260-266.

[98] S. Yang, B. Zhang, J. Wang, S. Liao, J. Han, J. Wie and L. Hou, Monoclonal antibodies against human telomerase reverse transcriptase (htert): preparation, characterization, and application, Hybridoma 20 (2001), 249-255. 


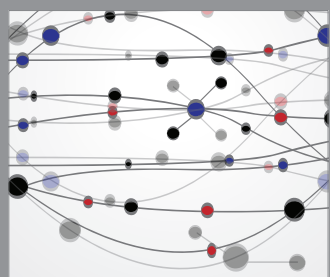

The Scientific World Journal
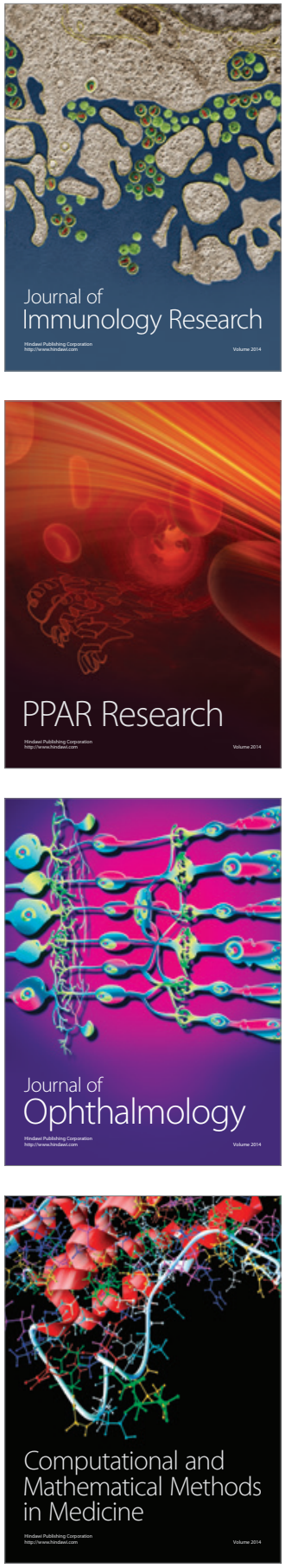

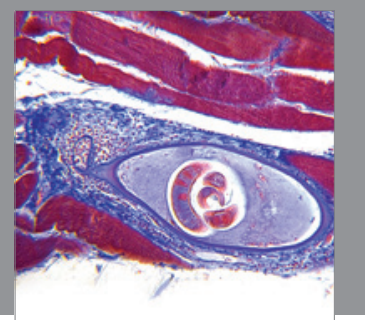

Gastroenterology

Research and Practice
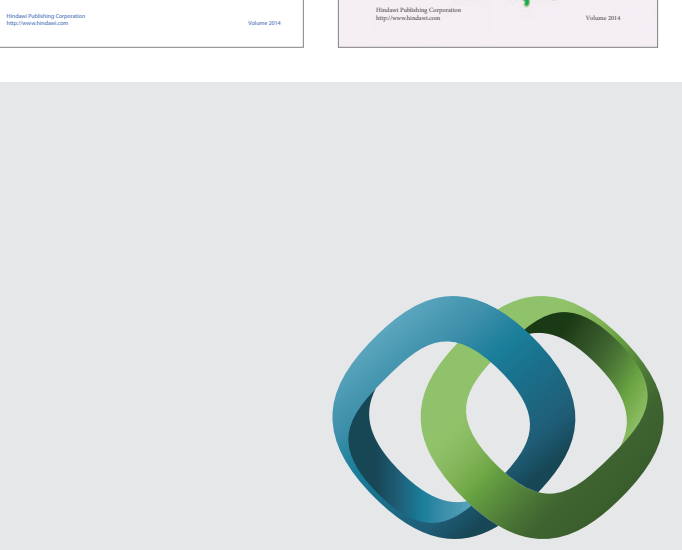

\section{Hindawi}

Submit your manuscripts at

http://www.hindawi.com
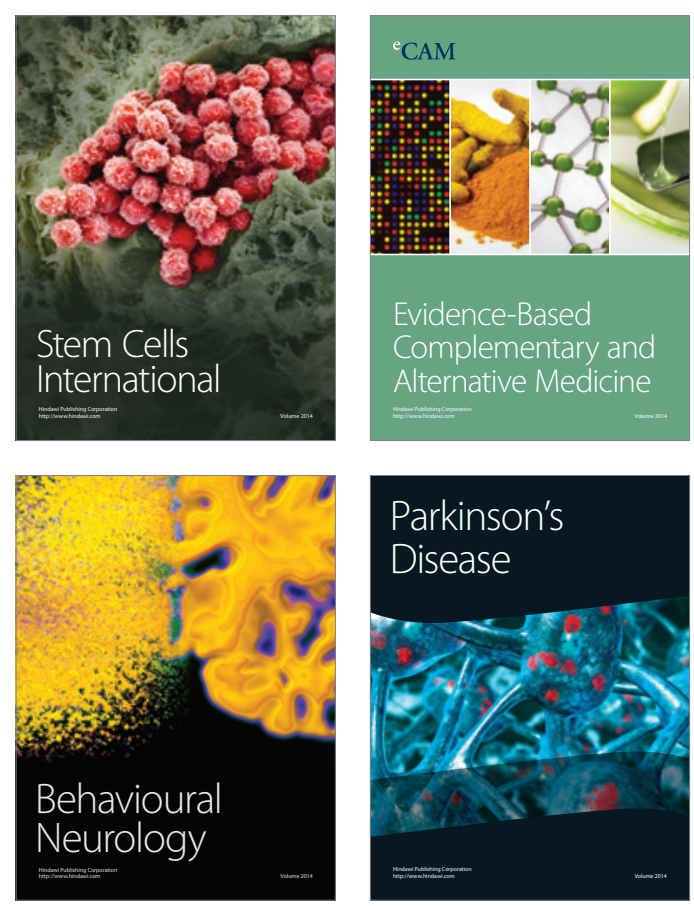

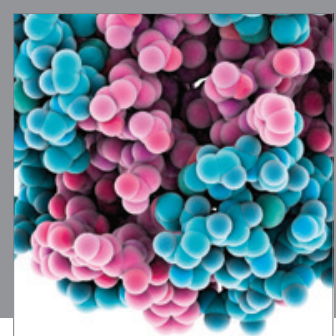

Journal of
Diabetes Research

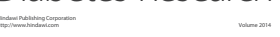

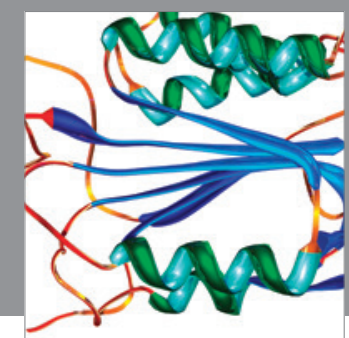

Disease Markers
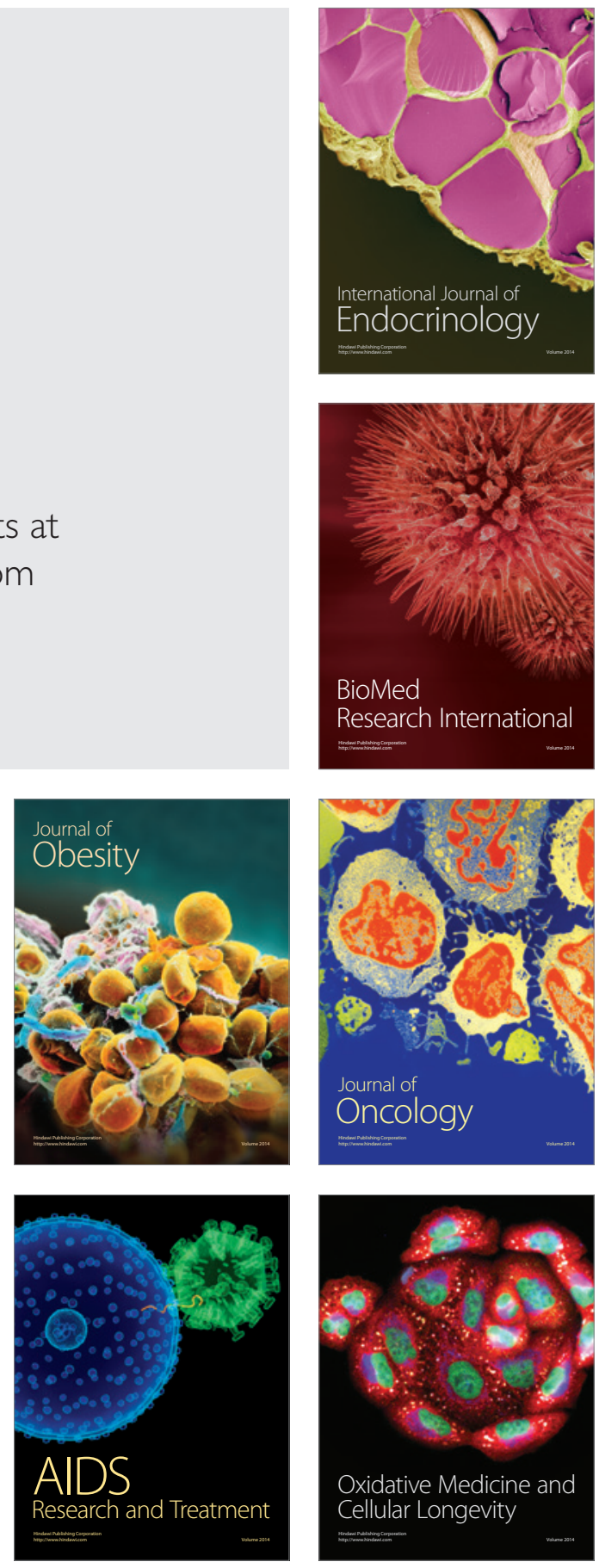